\title{
Evidence based rehabilitation in chronic pain syndromes
}

\author{
Kronik ăgrı sendromlarında kanıta dayalı rehabilitasyon
}

\author{
Gülseren AKYÜZ, Özlem ÖZKÖK
}

\section{Summary}

Chronic pain syndrome (CPS) is a complex condition that presents a major challenge to physicians because of its unknown etiology and poor response to all kinds of therapies. It has been suggested that chronicity should be considered when pain persists longer than the acceptable healing time. The impact of chronic pain on patients' lives varies from minor limitations to complete loss of independence. The rehabilitation in CPSs is multi-disciplinary and involves physical, occupational, and manual therapy, aquatherapy, cognitive/behavioral therapy, biofeedback, psychotherapy, and some new therapies. In recent years, the point of view in chronic pain management has changed substantially and CPS is managed best with a multidisciplinary approach, including a rehabilitative process. The treatment protocol should be planned and modified individually. A combination of several methods has been tried, but long-term evidence-based studies are needed for new treatment modalities.

Key words: Chronic pain syndromes; new rehabilitative methods; pain rehabilitation.

\section{Özet}

Kronik ağrı sendromu kompleks bir durum olup etyolojisinin net olmamast ve değişik tedavilere iyi yanıt alınamamast ile bekimler tarafından büyük bir bilinmezlik olarak kabul görmektedir. Kronisite, beklenen iyileşme sürecinden sonra da ağrının devam etmesi şeklinde yorumlanır. Hastaların yaşamı üzerine kronik ağrının etkisi hafif kısıtlanmadan bağımsızlı̆̆ın tümden kaybedilmesine kadar değişen bir yelpazede ortaya çıkar. Kronik ağrı sendromlarının rebabilitasyonu çok alanl yaklaşım gerektirir ve fizyoterapi, uğraşı terapisi, manuel terapi, akuaterapi, bilişsel/davranışsal terapi, biofeedback, psikoterapi ve diğer birçok yeni tedavi yöntemini içerir. Son yıllarda, kronik ağrı tedavisine bakış büyük oranda değişmiş ve en iyi yaklaşımın çok alanlı olduğu, rehabilitatif sürecin tedaviye dabil edilmesi gerektiği anlaşılmıştır. Tedavi protokolü bireysel olarak planlanmalı ve gerektiğinde modifiye edilmelidir. Birçok metodun kombine edilmesi söz konusu ise de özellikle yeni tedavi seçenekleri üzerinde uzun dönemde yapılmı̧ kanıta dayalı çalı̧̧malara ibtiyaç vardır.

Anahtar sözcükler: Kronik ağıı sendromlarl; yeni rehabilitatif yöntemler; ağrı rehabilitasyonu. 


\section{Introduction}

Pain is one of the most popular titles of medicine that can be classified according to neurophysiological mechanisms, duration, etiology, region and a lot of other properties. There is no standardization in any of these classifications. When the duration is taken into account, pain can be categorized as acute and chronic pain. Acute pain which is a symptom of a medical problem, has been seen as a vital protective mechanism. On the contrary, chronic pain is a useless and unpleasant condition. There are several expectations for the duration of chronic pain in different resources. International Association for the Study of Pain (IASP) determined the time limitation of chronic pain as 3 months. However, chronic pain is not a symptom, it is a syndrome. It has been shown that duration is not important in pathophysiology because chronic pain response can occur even in a short period. This situation that develops independent of duration is not a protective reaction as acute pain is. Chronic pain is also independent of tissue damage. So the pathophysiology of chronic pain is multifactorial and little is known in the transition from acute to chronic pain. Chronic pain syndrome (CPS) is a complicated situation. There are a lot of neurophysiological studies about the conduction of pain. ${ }^{[1]}$ It is concerned with multiple factors. If a patient does not improve himself despite a proper medical treatment or if his pain behavior, exaggerate over the expected response, we should consider CPS. It has been suggested that CPS might be a learned behavioral syndrome that occurring from noxious stimuli. Patients with CPS demonstrate some typical characteristics which are called Sternbach's 6 Dimensions. ${ }^{[2]}$ These typical characteristics are; dramatization of complaints, drug misuse or overuse, dysfunction, dependency, depression and disability. There are many CPSs in dealing with musculoskeletal, neurological systems, and visceral organs, e.g. sometimes multiple contributing factors may be seen in the same patient. Fibromyalgia syndrome (FS), chronic fatigue syndrome (CFS), myofascial pain syndrome (MPS), osteoarthritis (OA), mechanical low back pain and chronic overuse syndromes are the most common musculoskeletal system disorders. ${ }^{[3]}$ Indeed, the list is so long to demonstrate here but we should keep in mind that all type of diseases have the potential to turn into
CPS. CPS patients typically have reduced physical activity, impaired sleep, depressive symptoms, social withdrawal, fatigue, strong somatic focus, memory and cognitive impairments, less interest in sex, relationship problems, medication abuse, helplessness, hopelessness, alcohol addiction, guiltiness, anxiety, poor self-esteem and loss of employment. Each patient can be unique in the distribution of these symptoms and conditions.

\section{Pain rehabilitation}

Rehabilitation in CPS requires a multidisciplinary approach. The physician should evaluate the patients with CPS not only for pain but also physical, social and psychological aspects of the patient. ${ }^{[4]}$

In the rehabilitation process we aim to;

- Improve physical abilities (e.g., increase range of motion, standing, walking)

- Prevent further loss of function,

- Increase functional independence (e.g., increase activities of daily living, social-recreational activities, home-domestic activities),

- Maintain quality of life,

- Improve the vocational/disability status (e.g., return to work, start job retraining),

- Reduce/discontinue opiate and sedative-hypnotic medications,

- Decrease healthcare utilization for the CPS (e.g., reduce medical procedures, inpatient admissions, outpatient office visits)

- Reduce the pain level. ${ }^{[5]}$

Providing the person highest possible level of function can only be possible with a team work. This team includes physiatrist, physiotherapist, occupational therapist, recreational therapist, speech therapist, nurse, social worker, psychologist, and consultant physicians if necessary. Each member of this team works in different components of pain rehabilitation with leading of the physiatrist (Table 1).

\section{Physical therapy}

Physical therapy has a wide variety of physiotherapy techniques, ranging from heat or cold applications, traction, massage, ultrasound (US) therapy, transcutaneous electrical nerve stimulation (TENS), 
Table 1. Rehabilitation therapies

\section{Conventional and new rehabilitation techniques in the treatment of CPS}

Physical therapy

Occupational therapy

Manual therapy/ massage

Aquatherapy

Biofeedback

Relaxation therapy

Cognitive behavioral therapy

Psychotherapy

Other therapies

stretching and strengthening exercises to manipulations to alleviate pain, increase flexibility and muscle strength and improve function. ${ }^{[6]}$

When hot pack and TENS applications which are self-administered, safe and inexpensive in women with fibromyalgia were compared with each other, it was found that the efficacies of both of these modalities were equal in temporary pain reduction. ${ }^{[7]}$ Also different modalities of TENS have equal effect on fibromyalgia patients. ${ }^{[8]}$ Acupuncture like TENS application and stretch and spray technique are both effective methods in the treatment of myofascial pain syndrome. ${ }^{[9]}$ There are few randomized clinical trials (RCT) about US. A study which have been designed for the patients with low back pain about efficacy of US, has been continuing and the results have not been published yet. ${ }^{[10]}$ So, more research on US therapy are needed.

Therapeutic exercise is an important part of physical therapy which helps muscles weakened by disease or injury. These are range of motion (ROM), stretching, strengthening and general cardiovascular conditioning exercises. The objective of Ottawa Panel Evidence-Based Clinical Practice Guidelines for aerobic fitness exercises in the management of fibromyalgia was to create some criteriae for the use of these types of exercises. In this panel, 13 RCTs and 3 controlled clinical trials were included and aerobic fitness exercises have been recommended strongly. ${ }^{[11]}$ In another study, 30 minutes of self-selected life style physical activity throughout the day produces clinically relevant changes in perceived physical function and pain in previously minimally active adults with FS. ${ }^{[12]}$ Twenty eight RCTs comparing aerobic exercises with controls and seven RCTs comparing different types of aerobic exercises with a total of 2.494 patients were reviewed. When the efficacy of aerobic exercises were evaluated, the authors decided that an aerobic exercise program for FS patients should consist of land-based or waterbased exercises with slight to moderate intensity two or three times per week for at least 4 weeks. However, the patients should be motivated to continue the long term exercise program. ${ }^{[13]}$

There are many studies about the applications of physical agents in patients with MPS. Both diclofenac phonophoresis and US have been found effective equally in the treatment of patients with MPS. ${ }^{[14]}$ Ultrasound was also compared with ischemic compression techniques for the treatment of latent myofascial trigger points of trapezius muscle in healthy subjects. At the end of the study, the authors suggested that US was highly effective in the management of MPS. ${ }^{[15]}$ When pharmacotherapy and physiotherapy were compared in fibromyalgia patients, it was found that amitriptyline and physiotherapy had equal efficacy in 6 month follow-up. ${ }^{[16]}$ In a study that was designed for CFS patients, that is an educational intervention to encourage graded physical activity. They followed patients regularly whether they do the exercises or not for two years and observed that benefits of the intervention were maintained at two years. At the end of two years they found that the patients who did the exercises regularly had a greater benefit. ${ }^{[17]}$

\section{Occupational therapy}

Occupational therapy is a part of rehabilitation process improving the performance of the disabled people. The aim of occupational therapy is to help patients to adapt to their impairments, and achieve optimal function.

There are three categories of activities in occupational therapy: a) Activities of daily living, b) Work and productive activities, and c) Recreational or leisure activities. Recently, because of disability caused by CPS, the need for occupational therapy has been increasing. A review that concludes 23 studies reports 
that occupational therapy-related programs should incorporate multidisciplinary, patient-centered approaches focusing on patients' occupational needs to improve their workplace health and performance. ${ }^{[18]}$ However, there are recommendations for future research and practice for the effectiveness of occupation-based interventions for people with CPS. ${ }^{[19]}$

\section{Manual therapy}

Manual therapy is a type of treatment that skilled, specific hands-on techniques are used, including manipulation and mobilization. Physiatrists use manual therapy to diagnose and treat soft tissues and joint structures for decreasing pain, increasing range of motion (ROM), reducing or eliminating soft tissue inflammation, inducing relaxation, improving contractile and non-contractile tissue repair, extensibility and/or stability, facilitating movement, and improving function. In mobilization techniques, a manual approach is used to handle tissues including the muscles and the fasciae. Myofascial release is a method of soft tissue mobilization that focuses on the fascial component, which is believed to cause pain and dysfunction. Myofascial release techniques can help to improve pain and quality of life in patients with fibromyalgia. ${ }^{[20]}$

\section{Massage therapy}

Massage therapy has been defined as soft-tissue manipulation which is done by trained therapists for therapeutic purposes. ${ }^{[21]}$ It has a long history beginning in China. Massage can be applied to single or multiple body parts or to the entire body. There are many different types of massage therapy including Swedish massage, Shiatsu, Rolfing, reflexology and craniosacral therapy. ${ }^{[22]}$ It is increasingly used to manage chronic pain. There are lots of studies about effectiveness of massage therapy. A randomized controlled trial was designed to determine the effectiveness of a single session of nurse-administered massage for the short term relief of chronic non-malignant pain and anxiety. They concluded that massage is effective in a short term for the treatment of chronic pain. ${ }^{[23]}$ The physiological response of the muscle depends on the pattern of applied pressure during massage. It is consistent with a mechanism by which light-or moderate-pressure massage (or a combination) may reduce the gain of spinal nociceptive reflexes. As those reflexes are elevated in CPS, pressure variation provides a possible mechanism for the relief of CPS by massage therapy. ${ }^{[24]}$

\section{Aquatherapy}

Aquatherapy is a treatment modality that uses healing power of water. It has several subtypes such as hydrotherapy, tallasotherapy, balneotherapy, spa therapy. Hydrotherapy employs simply water while balneotherapy uses natural thermal water. Tallasotherapy denotes to therapy with sea water. Spa therapy includes hydrotherapy and balneotherapy. It also has a special therapeutic atmosphere. ${ }^{[25]}$ The mechanisms of action of aquatherapy in the treatment of chronic pain are not clear, but most probably the benefits could be derived from mechanical, physical and chemical factors. Muscle tone and pain intensity can be positively influenced by mud packs and thermal baths. In a review from Italy, it is confirmed that spa therapy should be a valid tool in the multidisciplinary approach of the FS. ${ }^{[26]}$ However, studies in large populations that evaluate the efficacy of aquatherapy are needed.

\section{Biofeedback}

Biofeedback is a new alternative modality for CPS. Computers and surface electrodes are used in biofeedback in order to reveal patients' physiological events, in visual and auditory forms. Biofeedback works via central nervous system relaxation, and rises the endorphin levels up and forms the neuroendocrine basis of chronic pain control. ${ }^{[27]}$

In EMG biofeedback, multiple muscle sites are scanned and activity areas of these muscles are targeted for specific relaxation exercises. Since continuous muscle contraction for a long duration is a pain source, biofeedback helps training patients to eliminate co-contraction, and teaches them to return their muscles to electrical silence after contraction. Biofeedback is determined as a treatment modality that reduces pain in patients with FS. Significant improvement in fibromyalgia impact questionnaire (FIQ), six minute walk test and the number of tender points in these patients were found. ${ }^{[28]}$ 


\section{Relaxation therapy}

Relaxation therapies ameliorate anxiety, autonomic activity, and muscle tension, seen in chronic pain. Imagery, progressive muscle relaxation, controlled breathing, or listening to relaxation tapes are widely for the management of CPS. Another advantage of these techniques is environmental adjustability. Tai Chi is originated as a martial art in China. It is composed of meditation with gentle movements, such as deep breathing and relaxation, to release vital energy throughout the body. It has been accepted as a multicomponent process which integrates physical, psychosocial, emotional components. ${ }^{[29]}$ Because of its mind-body attributes, Tai Chi could be especially suitable for the treatment of FS. There is a few studies in patients with FS about the effectiveness of Tai Chi. ${ }^{[30]}$ So, we believe that Tai Chi as one of the relaxation therapy methods should be recommended for the treatment of FS but well designed long-term and larger studies are needed.

\section{Cognitive behavioral therapy (CBT)}

Cognitive behavioral therapy is an evidence based psychological approach for the treatment of mental health and other personal and family problems. The main aim of cognitive therapy is to identify and correct negative thoughts which have become "automatic" because of repetition. Automatic thoughts occur at the point of experiencing or recalling a situation. ${ }^{[31]}$ In depression and anxiety many more negative thoughts occur than others, and lead to painful reactions. Individuals having anxiety disorders suffer from a repeating cycle of problematic thoughts. Internet-based cognitive behavioral therapy could serve as a complement for individuals with chronic pain who prefer this treatment and have difficulties accessing specialist treatment facilities. ${ }^{[32]} \mathrm{CBT}$ is a new therapeutic approach in the management of CPS, however, more research and people working in this field are required.

\section{Psychotherapy}

Psychotherapy is a process in which a professional has contact with patients in order to help their mental problems. The main goal of psychotherapy is to treat behavioral and mental disorders; remove negative symptoms. It contributes to improvement of the individual's relationships. In a study, it was shown that identifying patients with co morbid depression and chronic pain and offering Interpersonal Psychotherapy for Depression and Pain (IPT-P) as a treatment option had the potential to improve clinical outcomes for individuals with depression and chronic pain. ${ }^{[33]}$

\section{Other therapies}

There are also lots of other treatment modalities such as dry needling, acupuncture, and pet therapy which have been used in the treatment of CPS.

Dry needling is a relatively new modality. It has a low risk. It is easy to learn, cheap and minimally invasive. Its effectiveness has been depicted in numbers of studies and 2 comprehensive systematic reviews. ${ }^{[34]}$

Acupuncture is a component of alternative medicine that originated in China over 5,000 years ago, involving the insertion of solid filiform acupuncture needles into the skin at specific points on the body to achieve a therapeutic effect. No drug is injected. Acupuncturists insert needles into specified points along meridian lines to influence the restore balance to the flow of vital energy. In a multicentered randomized controlled study, total of 9,990 patients with chronic low back pain, headache, neck pain, knee and hip pain were treated by 2,781 physicians were analyzed. Two groups had the routine treatment, acupuncture group had also acupuncture. The outcome was markedly improved in the acupuncture group. ${ }^{[35]}$

Pet therapy is a new concept and is also known as animal assisted therapy (AAT). It is used for disabled people for a long time but recent studies have shown that petting an animal may lead to increased endorphin. Increased release of endorphin result in suppressed pain response. Since there are psychological factors in the etiology of CPS, pet therapy has benefits in these patients. ${ }^{[36-38]}$ When the psychological benefits are added, pet therapy seems a better choice for chronic pain patients.

\section{Conclusion and future perspectives}

The management of CPS requires multidisciplinary 
approach and rehabilitation is an important element of this treatment. If we look into current evidence about rehabilitation in CPS, National Institute for Health and Clinical Excellence (NHS) guideline covers the early treatment and management of persistent or recurrent low back pain, defined as non-specific low back pain that has lasted for more than 6 weeks, but for less than 12 months. It does not address the management of severe disabling low back pain that has lasted over 12 months. According to NICE-2009, it was recommended that patients with low back pain do more physical activity, and be informed about their back problems. ${ }^{[39]}$ It is also advised to perform local injection and combine physical therapy methods, rehabilitative and psychological approaches.

The last century has presented us new evidence about functional dynamics and independence of the cell together with genetics and molecular biology. Even though one cell cannot decide itself, it was shown with tumor formation that several cells can behave differently after a while. In chronic pain, they say that cell stores the pain in its memory and thoughts about how and why is the pain produced and how pain changes the patient's behaviors are emphasized. This situation is an evidence of the resistance of at least some patients to treatment. The first question in the mind of the physicians should be oriented to how the patient perceives the situation. It is important to determine the dependency of the patient to disease and the place of the patient on the line between seeming to want to be treated and really want to be treated. If the chronic pain takes role in reinforcing the patient's place in the family and if there are a lot of secondary benefits of patients from the disease/pain, the resistance to the treatment is understandable. In these types of patients, the result will be negative even though the physician tries to do the best. In chronic pain, non-opioid drugs decrease the pain, but do not eliminate it at all. Also medical and surgical interventions are not sufficient alone. Pain rehabilitation process should also be integrated to all kind of therapies.

In conclusion, there is no algorithm in the treatment of CPS in the world. A combination of several methods has been tried, but, long term evidencebased studies are needed especially for new treatment modalities.

\section{References}

1. Akyüz G, Güven Z, Ozaras N, Kayhan O. The effect of conventional transcutaneous electrical nerve stimulation on somatosensory evoked potentials. Electromyogr Clin Neurophysiol 1995:35(6):371-6.

2. Tang NK, Salkovskis PM, Hodges A, Soong E, Hanna MH, Hester J. Chronic pain syndrome associated with health anxiety: a qualitative thematic comparison between pain patients with high and low health anxiety. Br J Clin Psychol 2009;48(Pt 1):120.

3. Akyüz G, Bulak E. Osteoarthritis and pain. [Article in Turkish] Agri 2007;19(1):31-5.

4. McAllister MJ, McKenzie KE, Schultz DM, Epshteyn MG. Effectiveness of a multidisciplinary chronic pain program for treatment of refractory patients with complicated chronic pain syndromes. Pain Physician 2005;8(4):369-73.

5. Sanders SH, Harden RN, Vicente PJ. Evidence-based clinical practice guidelines for interdisciplinary rehabilitation of chronic nonmalignant pain syndrome patients. Pain Pract 2005;5(4):303-15.

6. Sepici V, Akyüz Babacan G. Transkütan elektrik sinir stimülasyonu. İçinde: Tuna N, editör. Elektroterapi. İstanbul: Nobel Kitabevi; 1989. s. 157-70.

7. Löfgren $M$, Norrbrink C. Pain relief in women with fibromyalgia: a cross-over study of superficial warmth stimulation and transcutaneous electrical nerve stimulation. J Rehabil Med 2009;41(7):557-62.

8. Güven Z, Özaras N, Kayhan Ö, Akyüz G, Ünaldi E. The effect of different TENS modalities on pain in fibromyalgia syndrome. Scandinavian Journal of Rheumatology 1992;Supp 94:135.

9. Akyüz G, Erden E, Ozaras N, Guven Z, Kayhan O. Myofasyal ağrı sendromu tedavisinde germe ve sprey tekniği ile akupunktür benzeri transkütan elektrik sinir uyarımının etkinliği. Ağrı 1995;7(2):28-31.

10. Ebadi S, Ansari NN, Henschke N, Naghdi S, van Tulder MW. The effect of continuous ultrasound on chronic low back pain: protocol of a randomized controlled trial. BMC Musculoskelet Disord 2011;16:12-59.

11. Brosseau L, Wells GA, Tugwell P, Egan M, Wilson KG, Dubouloz CJ, et al; Ottawa Panel Members. Ottawa Panel evidencebased clinical practice guidelines for aerobic fitness exercises in the management of fibromyalgia: part 1. Phys Ther 2008;88(7):857-71.

12. Fontaine KR, Conn L, Clauw DJ. Effects of lifestyle physical activity on perceived symptoms and physical function in adults with fibromyalgia: results of a randomized trial. Arthritis Res Ther 2010;12(2):R55.

13. Häuser W, Klose P, Langhorst J, Moradi B, Steinbach M, Schiltenwolf $M$, et al. Efficacy of different types of aerobic exercise in fibromyalgia syndrome: a systematic review and metaanalysis of randomised controlled trials. Arthritis Res Ther 2010;12(3):R79.

14. Ay S, Doğan SK, Evcik D, Başer OC. Comparison the efficacy of phonophoresis and ultrasound therapy in myofascial pain syndrome. Rheumatol Int 2011;31(9):1203-8.

15. Aguilera FJ, Martín DP, Masanet RA, Botella AC, Soler LB, Morell FB. Immediate effect of ultrasound and ischemic compression techniques for the treatment of trapezius latent myofascial trigger points in healthy subjects: a randomized controlled study. J Manipulative Physiol Ther 2009;32(7):515-20.

16. Joshi MN, Joshi R, Jain AP. Effect of amitriptyline vs. physio- 
therapy in management of fibromyalgia syndrome: What predicts a clinical benefit? J Postgrad Med 2009;55(3):185-9.

17. Powell P, Bentall RP, Nye FJ, Edwards RH. Patient education to encourage graded exercise in chronic fatigue syndrome. 2-year follow-up of randomised controlled trial. Br J Psychiatry 2004;184:142-6.

18. Snodgrass J. Effective occupational therapy interventions in the rehabilitation of individuals with work-related low back injuries and illnesses: a systematic review. Am J Occup Ther 2011;65(1):37-43.

19. Robinson K, Kennedy N, Harmon D. Review of occupational therapy for people with chronic pain. Aust Occup Ther J 2011;58(2):74-81. doi: 10.1111/j.1440-1630.2010.00889.x.

20. Castro-Sánchez AM, Matarán-Peñarrocha GA, Granero-Molina J, Aguilera-Manrique G, Quesada-Rubio JM, Moreno-Lorenzo C. Benefits of massage-myofascial release therapy on pain, anxiety, quality of sleep, depression, and quality of life in patients with fibromyalgia. Evid Based Complement Alternat Med 2011;2011:561753.

21. Field TM. Massage therapy effects. Am Psychol 1998;53(12):1270-81.

22. Tsao JC. Effectiveness of massage therapy for chronic, nonmalignant pain: a review. Evid Based Complement Alternat Med 2007;4(2):165-79.

23. Seers K, Crichton N, Martin J, Coulson K, Carroll D. A randomised controlled trial to assess the effectiveness of a single session of nurse administered massage for short term relief of chronic non-malignant pain. BMC Nurs 2008;7:10.

24. Roberts L. Effects of patterns of pressure application on resting electromyography during massage. Int J Ther Massage Bodywork 2011;4(1):4-11.

25. Bender T, Karagülle Z, Bálint GP, Gutenbrunner C, Bálint PV, Sukenik S. Hydrotherapy, balneotherapy, and spa treatment in pain management. Rheumatol Int 2005;25(3):220-4.

26. Giannitti C, Bellisai B, lacoponi F, Petraglia A, Fioravanti A. New evidences on spa therapy in fibromyalgia. [Article in Italian] Clin Ter 2008;159(5):377-80. [Abstract]

27. Basmajian JV. Part I - Introduction neuroscience Biofeedback in Principles and practice for clinicians. 3rd ed., Baltimore: Williams and Wilkins; 1989. p. 1-4.

28. Babu AS, Mathew E, Danda D, Prakash H. Management of patients with fibromyalgia using biofeedback: a randomized control trial. Indian J Med Sci 2007;61 (8):455-61.

29. Wayne PM, Kaptchuk TJ. Challenges inherent to t'ai chi research: part l--t'ai chi as a complex multicomponent intervention. J Altern Complement Med 2008;14(1):95-102.

30. Wang C, Schmid CH, Rones R, Kalish R, Yinh J, Goldenberg DL, Lee $Y$, McAlindon T. A randomized trial of tai chi for fibromyalgia. N Engl J Med 2010;363(8):743-54.

31. Bernardy K, Füber N, Köllner V, Häuser W. Efficacy of cognitivebehavioral therapies in fibromyalgia syndrome-a systematic review and metaanalysis of randomized controlled trials. J Rheumatol 2010;37(10):1991-2005.

32. Buhrman M, Nilsson-Ihrfeldt E, Jannert M, Ström L, Andersson G. Guided internet-based cognitive behavioural treatment for chronic back pain reduces pain catastrophizing: a randomized controlled trial. J Rehabil Med 2011;43(6):500-5.

33. Poleshuck EL, Gamble SA, Cort N, Hoffman-King D, Cerrito B, Rosario-McCabe LA, Giles DE. Interpersonal Psychotherapy for Co-occurring Depression and Chronic Pain. Prof Psychol Res Pr 2010;41(4):312-318.

34. Kalichman L, Vulfsons S. Dry needling in the management of musculoskeletal pain. J Am Board Fam Med 2010;23(5):640-6.

35. Witt CM, Schützler L, Lüdtke R, Wegscheider K, Willich SN. Patient characteristics and variation in treatment outcomes: which patients benefit most from acupuncture for chronic pain? Clin J Pain 2011;27(6):550-5.

36. Muñoz Lasa S, Franchignoni F. The role of animal-assisted therapy in physical and rehabilitation medicine. Eur J Phys Rehabil Med 2008;44(1):99-100.

37. Cole KM, Gawlinski A, Steers N, Kotlerman J. Animal-assisted therapy in patients hospitalized with heart failure. Am J Crit Care 2007;16(6):575-85.

38. Berget B, Ekeberg O, Braastad BO. Animal-assisted therapy with farm animals for persons with psychiatric disorders: effects on self-efficacy, coping ability and quality of life, a randomized controlled trial. Clin Pract Epidemiol Ment Health 2008;11;4:9.

39. Savigny P, Watson P, Underwood M; Guideline Development Group. Early management of persistent non-specific low back pain: summary of NICE guidance. BMJ 2009;4:338:b1805. 